\title{
Concern mounting over French government action on AIDS
}

Paris

THE four-month-old French government can no longer be in doubt that it will have to change the pace of national measures to combat the spread of AIDS. La rentrée - the return to work after the two-month holiday period - is always accompanied by an impatience to set everything to rights. But a series of independent broadsides in the press from eminent workers in the fields of public health and community care has pushed AIDS to the top of the pile on the health minister's desk.

The first public attack came from three eminent doctors. In the 9 September issue of the biweekly magazine, Nouvel Observateur, Leon Schwartzenberg, whose career as Minister Delegate for Health in the new government lasted only nine days (see Nature 334, 461; 1988), Jean-Claude Chermann, who, with Luc Montagnier, first isolated the human immunodeficiency virus (HIV), and Paul Milliez, honorary dean of the BroussaisHôtel-Dieu faculty of medicine in Paris, call upon those in power "who have not yet, it appears, appreciated the extent of the danger, to take action, at government level, to tackle screening for and information about AIDS".

"We ask the French public to accept generalized but voluntary screening. This alone will enable us to know who is carrying the virus and who is not", says their open letter. "It would be desirable that these tests be reimbursed by the Social Security. But, in order not to endanger the financial stability of the Social Security and to accelerate the process, we appeal to all French citizens who are able to, to pay for their own AIDS test at a cost of FF103 $(\$ 16.50)$ per year".

The authors would like to see screening targeted "not only at populations whose behaviour puts them at risk, but also at pregnant women, those intending to marry, those undergoing surgery, indeed, all those who are sexually active and especially the young, who are particularly exposed".

The letter, in fact, calls for little that is not at present carried out, albeit haphazardly. Several maternity hospitals, on their own initiative, already advise expectant mothers to be screened. Screening for HIV is available to all on a voluntary basis in 400 laboratories and 113 screening centres, even if their infrastructure is often said to be wanting. The cost of the test is also refunded for those with Social Security insurance. But the Social Security system is running a huge deficit and would be unable to cope with massive use of state-reimbursed voluntary tests.

What is lacking is a high-profile co- ordinated programme of information, counselling, care and targeted screening, as Daniel Defert, president of a leading national and voluntary action group, AIDES, points out in the daily newspaper, Libération. But Defert disagrees with Schwartzenberg's suggestion that political motives alone are responsible for the absence of 'generalized' screening for HIV antibodies. "If screening has not been generalized, it is not because of a fear of impinging on individual freedoms, but for medical reasons, as researchers and clinicians repeatedly point out". Defert does, however, echo a growing feeling that successive governments have not grasped the nettle in their public health campaigns for fear of shocking public morals.

Defert agrees with Schwartzenberg and his cosignatories that government action is inadequate in the face of an annual doubling of AIDS sufferers in France.

Health minister, Claude Evin, has so far kept a low profile in the face of these attacks and is unlikely to announce government plans before October. By then he should have had time to digest the report, commissioned at the end of August and due in two weeks, to advise him what steps he should take (see Nature 335, 2; 1988).

Peter Coles

- French government financing of AIDS research has also come under attack. Speaking at the Third International Conference on AIDS in Arusha, Tanzania, Luc Montagnier has again decried what he feels to be the low level of support for AIDS research. New grants for research on AIDS have dropped from FF100 million (\$16.13 million) last year to FF20 million for 1988. But in a Research Ministry reply, minister Hubert Curien explains that FF50 million of last year's allocation was not spent. This sum has been carried forward for 1988 , bringing the total grant to FF70 million.

\section{Report cites unemployment as major health risk in Britain}

\section{London}

FreE condoms, health warnings on alcoholic drinks, an absence of cigarette advertisements and mandatory rear seatbelts are just a few features of the new, healthier Britain that could be created if the government heeds the recommendations of an independent committee which has carried out a comprehensive study of the nation's health. In its report, published this week, existing health policies are severely criticized and increased funding for health promotion is called for.

The study was undertaken by an independent multidisciplinary committee sponsored by the Health Education Authority, the Scottish Health Education Group, the London School of Hygiene and Tropical Medicine and the King Edward's Hospital Fund for London.

Comparisons made with other European countries show that progress in public health in Britain has been neglected, inequalities within the country are glaring and the development of health promotion agencies has been uncoordinated, says the report. "There is an overriding need for the development of a coherent, long-term plan for the public health." That will include increased funding for national education programmes, the Sports Council and cancer screening services.

The tobacco, alcohol and confectionery manufacturers together spend almost $£ 700$ million annually on promoting products which represent hazards to health. In 1985-86, this represented more than 50 times the total budget of the bodies responsible for health education.

Some specific recommendations are sure to arouse fierce opposition. The committee recommends that an annual levy be raised on the advertising of food, alcohol and tobacco, which would be used to promote good health. A 10 per cent levy on cigarettes would raise $£ 10$ million, it says. It also recommends new tar classifications - dangerous (under $5 \mathrm{mg}$ per cigarette) and very dangerous (5-10 $\mathrm{mg}$ per cigarette).

It recommends warnings to consumers on what constitutes excessive or unsafe patterns of drinking; no further relaxation of the licensing laws and stiffer penalties for drinking and driving.

The report calls for a more coherent strategy to prevent AIDS and other sexually transmitted diseases. Condoms should be available on prescription from general practitioners, should be more widely available and should undergo mandatory quality testing.

One aspect of the report likely to embarrass the government is the link between health and socio-economic status, particularly with the unemployed. There are 1,500 extra deaths every year associated with unemployment for every million employed. The number of suicides among the unemployed is double that of the employed. This is the area in which major gains can be most readily achieved, the report says. "A reduction in unemployment is likely to have a major benefit on wide-ranging aspects of health."

Christine McGourty 